\title{
ISLAMIC GARDEN CONCEPT IN BUSTANUSSALATIN (GARDEN OF THE KINGS), ACEH, INDONESIA
}

\section{Nurul Fakriah}

Department of Architecture

State Islamic University of Ar-Raniry

Banda Aceh, Indonesia

nurul.fakriah@ar-raniry.ac.id

\begin{abstract}
In the $17^{\text {th }}$ century, Nuruddin Ar-Raniry wrote a manuscript about the Aceh Kingdom, namely Bustanussalatin, which means the garden of the kings. Following the working title, in one part of the chapter, he described the garden lied in the kingdom in detail. This study aims to determine if the garden existed in that era can be delivered as an Islamic garden, considering the Kingdom was ruled based on Islamic law. To answer that, analysis the part of Bustanussalatin which described the garden was carried out using the content analysis method. The coding and sorting based on the concept of Islamic garden based on Islamic source, which is the Quran and Hadits, which has been carried out by other research. The result showed that the garden implemented the Islamic garden concept in picturing the garden in Heaven. However, it can not be denied that some restriction in sharia was disobeyed in the garden in using the elements of the historical garden,
\end{abstract}

\section{KEYWORDS:}

Bustanussalatin, Aceh historical garden, Islamic landscape, the garden of the kings

\section{INTRODUCTION}

Nuruddin Ar-Raniry wrote in his famous manuscript, Bustanussalatin (which means: garden of the kings), about the garden in the Aceh Kingdom in the $17^{\text {th }}$ century in one of his chapters of his work [1]. This garden's name was "Taman Ghairah," which was built by Sultan Iskandar Muda and finished by his son-in-law, Sultan Iskandar Thani [1][2] [3]. Sulthan Iskandar Thani assigned Ar-Raniryni to write about the Kingdom. The work contained several chapters in historichroordercal [3]. The description of the historical garden in the Aceh Kingdom was only a piece of the great work of $\mathrm{Ar}$ Raniry. However, the narrative was very detailed [1]. During the era of the Sultanate or the Islamic Kingdom, Aceh was ruled by the Kings (and also Queens, after the death of the last King in the $17^{\text {th }}$ century) based on Islamic law [1] [4].

Until now, the Islamic garden which became a reference to many scholars was the garden palace complex Alhambra Granada in Spain, the garden of Taj Mahal in India, and the garden in Persia [5][6][7]. The location of the gardens considered as Islamic garden are where the Islamic Empire had existed. Those places were considered the heart of the Islamic World. The location of the Aceh Kingdom, which is geographically far from the heart of the Islamic World, caused it rarely mentioned as part of the Islamic World. However, historically, Aceh Kingdom played a significant role in spreading Islam in South East Asia [1][4] [8].

Referring to the fact that the Aceh Kingdom was the Islamic Kingdom, ruled by Islamic law, and played an essential role in spreading Islam in the area, it is arguable that the garden that existed in that era can be considered as an Islamic garden. Therefore, this study aims to figure out whether or not the garden mentioned in Bustanussalatin, which was existed in the $17^{\text {th }}$ century, can be considered as an Islamic garden.

\section{METHODS}

The method used in this study was content analysis from the work of Nuruddin Ar-Raniry, namely Bustanussalatin. The content analysis methodology is proper to evaluate the antecedents, message characteristics and properties, and consequences of the communication, including the manuscript text [9]. However, since the original manuscript is considered missing, and the copies are spread out worldwide, the source used in this study is based on the transliteration version as attached in Lombard's book [1]. To complete the part of the garden section from Bustanussalatin in Lombard's attachment, the work from Arief was also used to complete the vegetation list mentioned in Bustanussalatin [10].

This method intended to discover the nature of garden in the Aceh Kingdom in the $17^{\text {th }}$ century, then to compare to the literature which defined the concept of 
the Islamic garden. In this case, the work of Jannah et al. was used to measure whether or not the garden mentioned in Bustanussalatin can be considered an Islamic garden [11]. The Islamic garden's concept was used since it was based on the Qur'an and Hadits, which are the primary source of Islam. The chosen of this approach considering that the elements and characteristics of the garden in South East Asia can not be compared to the features and characteristic in the area of the heart of the Islamic World (such as the Middle East and others) due to the different character of the climate and the land. Therefore, choosing the Islamic concept based on what is mentioned in Islamic sources such as Qur'an and Hadits is the best approach for this study. Moreover, Poursafar also argued that the source of inspiration of the Islamic Garden in the heart of the Islamic World is from the Qur'an [12].

To achieve this aim, the transliteration text of Bustanussalatin firstly completes a condensation process before being coded and sorted into categories based on the criteria and subcriteria in each component of the Islamic garden's concept in Jannah et al. work. The coding process followed the keywords in each subcriteria. In this study, three components were compared, namely the elements, the characters, and the concepts of the garden. In the end, the boundary of sharia law is also reached and can be considered as the fourth component to find out whether or not the garden disobeyed the Islamic rules [11].

After categorizing, the process of synthesizing and theorizing was applied to determine the similarities between the keywords in Jannah et al.'s work and the code of the manuscript text. This was conducted to conclude whether or not the garden described in the manuscript in line with the Islamic garden concept as mentioned above.

\section{RESULT AND DISCUSSION}

\section{ELEMENT OF THE GARDEN}

The first component was compared between the garden in Aceh in the $17^{\text {th }}$ century to the Islamic garden reference is the element of the garden. It consisted of three criteria, namely soft scape, hardscape, and design elements [11]. The soft scape criteria consisted of three subcriteria which are water, vegetation, and animal. The hardscape criteria consisted of three subcriteria: buildings, doors, and other hardscapes. The last criteria, design elements, also consisted of three subcriteria: color, sound, and scent [11].

The keyword from each subcriteria was taken from the words often mentioned in the Quran and Hadits describing the garden in Heaven [11].

There are many verses in the Qur'an that mentioned the elements in Paradise. One of the verse in the Qur'an that describing the aspects in Paradise, for example, in the surah al Waqi'ah verses 28-34 as stated:

"They will be amid thornless lote trees, clusters of bananas, extended shade, flowing water, abundant fruit, never out of season nor forbidden, and elevated furnishings." [13]
The elements in Paradise also described in the surah Muhammad verse 15 as mentioned:

"The description of the Paradise promised to the righteous is that in it are rivers of fresh water, rivers of milk that never changes in taste, rivers of wine delicious to drink, and rivers of pure honey. There they will also have all kinds of fruit, and forgiveness from their Lord...." [13]

The description of the Aceh garden as mentioned in Bustanussalatin was explicitly and implicitly stated the elements of the garden as mentioned in the Islamic garden's concept accordingly. The result can be seen in table 1 .

From the comparison of the elements mentioned in the Quran as the concept of Islamic garden picturing the garden in Heaven and the component of Aceh garden mentioned in Bustanussalatin, it is seen that most of the elements in the Islamic garden concept were implemented in the Aceh garden.

All of the softscape elements were implemented in the garden, as mentioned in the manuscript, such as water, river, tree, fruits, and animals.

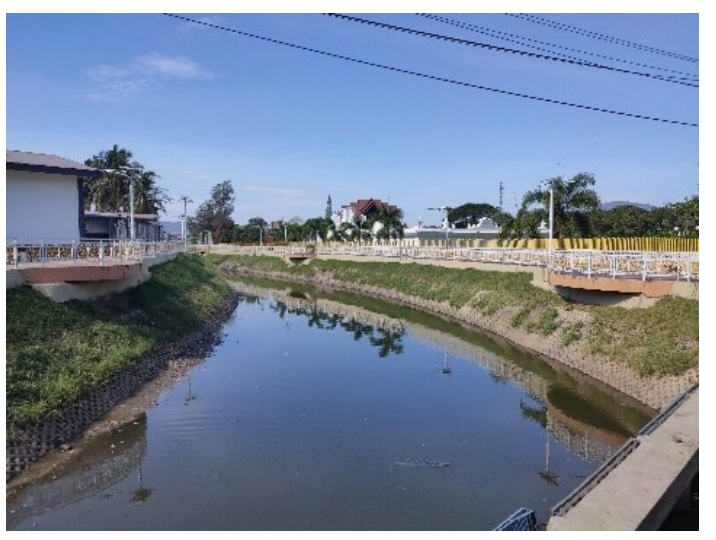

Figure 1. Darul Isyki, the historical artificial river on Taman Ghairah site (source: Author)

Most of the hardscape elements were also implemented and explicitly mentioned in the manuscript. The keyword 'house' mentioned in the manuscript was the house of pigeon, which is different from the Islamic garden concept. However, this different because of the different context in which the garden described in the manuscript was part of the palace, where the kings settled. Meanwhile, in the Quran, the mention of the house refers to the building where the resident of Heaven will be settled. In this context, the word 'house' should refer to the palace. The other hardscape elements such as pillow, carpet, coach, glasses, cup, and plate were not mentioned in Bustanussalatin because these elements are not common to exist in an outdoor environment. Therefore, these differences are understandable. However, the 'kenduri' activity that was being held in the garden may use glasses, cups, and plates in eating and drinking. 
Table 1. Element of The Garden

\begin{tabular}{|c|c|c|c|}
\hline Criteria & Subcriteria & Keyword & Bustanussalatin description \\
\hline \multirow[t]{2}{*}{ Softscape } & Water & $\begin{array}{c}\text { River } \\
\text { Water }\end{array}$ & $\begin{array}{l}\text { There was a river named Darul Isyki in the middle of the garden } \\
\text { The water in the river was crystal clear, cold, and healthy to one who drinks it. There were also } \\
\text { some pools in the garden (named Jantera Rasa, Jantera Hati, Cendera Hati). The other water } \\
\text { feature mentioned was the rose water in the Bath. }\end{array}$ \\
\hline & Vegetation & $\begin{array}{l}\text { Fruit } \\
\text { Tree }\end{array}$ & $\begin{array}{l}\text { Banana, Coconut, and many other fruits. } \\
\text { The vegetation mentioned was flowers, a giant tree beside the fishing spot, banana trees, } \\
\text { coconut trees, any kind of areca nut trees, and many other trees. }\end{array}$ \\
\hline \multirow[t]{9}{*}{ Hardscape } & $\begin{array}{l}\text { Animal } \\
\text { Buildings }\end{array}$ & $\begin{array}{l}\text { Bird } \\
\text { Place }\end{array}$ & $\begin{array}{l}\text { Animal mentioned in the manuscript were: many kinds of fishes and pigeon } \\
\text { Balai, Balai Kambang, artificial island (named Pulau Sangga Marmar), bath (named Sangga } \\
\text { Sumak), the fishing spot (named Tunjung Indrabangsa), artificial hill, tower (named Gegunun- } \\
\text { gan Menara Permata), Balai Cermin Perang, Masjid Isyki Musyahadah, Balai Rekaan Cina, Balai } \\
\text { Keemasan }\end{array}$ \\
\hline & & $\begin{array}{l}\text { Palace } \\
\text { House }\end{array}$ & $\begin{array}{l}\text { The palace was located in the north of the garden } \\
\text { There was a house for pigeons in the garden. Also, the palace has functioned as a settlement } \\
\text { for the King and his family. }\end{array}$ \\
\hline & $\begin{array}{l}\text { Doors } \\
\text { Other } \\
\text { Hardscape }\end{array}$ & $\begin{array}{l}\text { Door } \\
\text { Pillow }\end{array}$ & $\begin{array}{l}\text { The door of the garden called Pintu Biram Indrabangsa } \\
\text { - }\end{array}$ \\
\hline & & Carpet & - \\
\hline & & Coach & - \\
\hline & & Glass & - \\
\hline & & Cup & - \\
\hline & & Plate & - \\
\hline & & Basin & $\begin{array}{l}\text { There were two basin/vessel named Rambut Kemalai, and there were other two at the bank of } \\
\text { the pool named Kembang Caipu Cina and Peterana Sangga, a stone vessel named Kembang } \\
\text { Seroja }\end{array}$ \\
\hline \multirow{7}{*}{$\begin{array}{l}\text { Design } \\
\text { Elements }\end{array}$} & Colors & Green & The tree looked like a green umbrella. One layer of the Kandang's roof was green. \\
\hline & & Gold & $\begin{array}{l}\text { There were many gold accessories in the garden. Some fishes are in gold color. The top of the } \\
\text { Kandang's roof was made of gold (which means the color was gold). There was a golden porch } \\
\text { (named like that because the color was gold). Copper ties the stone stairs in gold color. The } \\
\text { top of the mosque is made of gold. }\end{array}$ \\
\hline & & $\begin{array}{l}\text { Silver } \\
\text { White }\end{array}$ & $\begin{array}{l}\text { There was rock brushed in silver color. The door of the 'Gegunungan' is made of silver. } \\
\text { There was rough sand in white color. The stone was bruised in white color. }\end{array}$ \\
\hline & Sound & $\begin{array}{l}\text { Red } \\
\text { Sound }\end{array}$ & \\
\hline & & Heard & $\begin{array}{l}\text { There is no specific information about what being heard in the garden mentioned in the manu- } \\
\text { script; however, from the description of the garden it is indicated that the natural sound was } \\
\text { heard in the garden, as well as the religious speak, as one must spell the shalawat (praise for } \\
\text { the Prophet) when entering the Kandang. }\end{array}$ \\
\hline & Scent & Musk & - \\
\hline & & $\begin{array}{l}\text { Scent } \\
\text { Smell }\end{array}$ & $\begin{array}{l}\text { The rose water fragrant of the Bath } \\
\text { There is no information about the smell, but there is an indication that the scent of the garden } \\
\text { was only fragrance because the number of the flower was numerous. }\end{array}$ \\
\hline
\end{tabular}

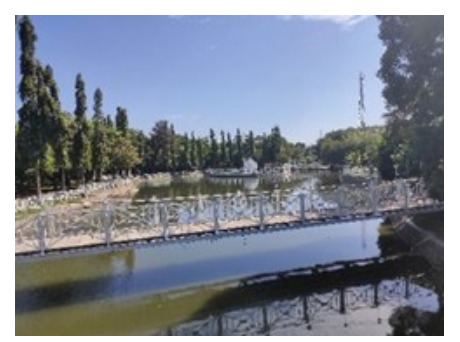

Figure 2. The view of Taman Putroe Phang (Putroe Phang Garden) nowadays, part of Taman Ghairah in the past (source: Author)

All the design elements mentioned in the Islamic source were also mentioned in the text, except for the word 'smell.' It also makes sense as the word 'scent' would be similar to the word 'smell' in a positive way. It also makes sense that the smell of the garden contains a fragrance scent-also, the non-existence of the musk scent understandable as the context of Asia's natural resource. Much other fragrance existed and can be used in the garden naturally as part of the garden element. For instance, the scent of rose was mentioned explicitly in the manuscript. Meanwhile, other flowers are said as plants that grow in the garden.

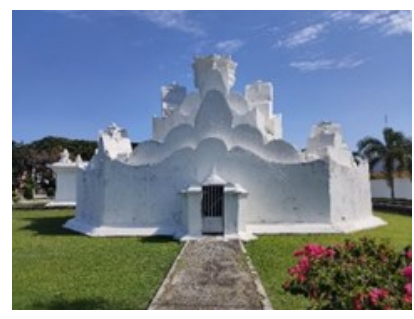

Figure 3. Gunongan, one of the buildings, remains on the Taman Ghairah site (source: Author) 


\section{CHARACTER OF THE GARDEN}

The second component that was compared is the character of the garden. It consisted of three criteria, physic character, non-physic character, and user character [11]. The first criteria, a physic character, consisted of three subcriteria, beauty, accessibility, and public area. The second one, the non-physic character, consisted of two subcriteria, safe, quiet, and recreative. The last criteria, the character of the user, consisted of four subcriteria: the type of the user, feelings of the user, clothes of the user, and the user's activity.

The Quran explained the condition of the Paradise inhabitants in surah Yasin verses $55-58$ as stated: "Indeed, on that Day, the residents of

Paradise will be busy enjoying themselves. They and their spouses will be in 'cool' shade, reclining on 'canopied' couches. There they will have fruits and whatever they desire. And 'peace' will be their greeting from the Merciful Lord" [13].

All of the subcriteria in each criterion were summarized from the Islamic source's keywords [11]. The description of the garden in Aceh in the $17^{\text {th }}$ century, as stated in Bustanussalatin, mentioned some of the keywords mentioned in the Quran and Hadits as Islamic sources. Meanwhile, the other keywords were implicitly described as the keywords in the Islamic source. The result of the comparison of the character of the garden can be seen in table 2 .

Table 2. The character of the garden

\begin{tabular}{|c|c|c|c|}
\hline Criteria & Subcriteria & Keyword & Bustanussalatin description \\
\hline \multirow[t]{5}{*}{$\begin{array}{l}\text { Physic Charac- } \\
\text { ter }\end{array}$} & Beauty & $\begin{array}{l}\text { Beautiful } \\
\text { Shady }\end{array}$ & $\begin{array}{l}\text { Beautiful } \\
\text { Shady }\end{array}$ \\
\hline & & Shade & Shade \\
\hline & & Spacious & Spacious \\
\hline & Accessibility & Near & $\begin{array}{l}\text { The gate of the garden side by side with the palace on the north side indicated } \\
\text { the easy accessibility }\end{array}$ \\
\hline & Public Area & Together in a group & $\begin{array}{l}\text { There is a place where the King held 'kenduri', which means public activity in a } \\
\text { crowd }\end{array}$ \\
\hline \multirow[t]{2}{*}{$\begin{array}{l}\text { Non-physic } \\
\text { Character }\end{array}$} & $\begin{array}{l}\text { Safe and } \\
\text { Quite }\end{array}$ & Safe & $\begin{array}{l}\text { It is not explicitly mentioned, but the description of the stone fence surround- } \\
\text { ed the garden indicated the safe environment at the garden }\end{array}$ \\
\hline & Recreative & As a reward & $\begin{array}{l}\text { There was a fishing spot for recreational purpose. There was also a lot of balai } \\
\text { and pools-all the description indicating the recreative purpose of the garden. }\end{array}$ \\
\hline \multirow[t]{9}{*}{$\begin{array}{l}\text { The character } \\
\text { of The User }\end{array}$} & $\begin{array}{l}\text { Type of The } \\
\text { User }\end{array}$ & Believer & $\begin{array}{l}\text { It is mentioned that whoever enters the 'Kandang' which was located in the } \\
\text { garden, reciting shalawat (praise for the Prophet) indicating the religious } \\
\text { state of the user. }\end{array}$ \\
\hline & & $\begin{array}{l}\text { Bertakwa (high level } \\
\text { of the believer) }\end{array}$ & Same information as above to indicate 'takwa' (high level of the believer \\
\hline & & Doing good deeds & $\begin{array}{l}\text { For consideration, 'kenduri' held by the King inviting people can be considered } \\
\text { as good deeds }\end{array}$ \\
\hline & $\begin{array}{l}\text { Feelings of } \\
\text { The User }\end{array}$ & $\begin{array}{c}\text { Excited } \\
\text { Pleased } \\
\text { Happy } \\
\text { Enjoy }\end{array}$ & $\begin{array}{l}\text { There was not much information about the feeling of the user except the part } \\
\text { when the user hears the sound of the flowing river. They would feel happy }\end{array}$ \\
\hline & $\begin{array}{l}\text { Clothes of } \\
\text { The User }\end{array}$ & $\begin{array}{l}\text { Clothing } \\
\text { Jewelry }\end{array}$ & There was no information about the clothes of the user in the garden \\
\hline & & Clothes & \\
\hline & $\begin{array}{l}\text { The activity of } \\
\text { The User }\end{array}$ & Sit & $\begin{array}{l}\text { The King sits at the fishing spot, the throne, and there is activity' kenduri'. This } \\
\text { activity usually eats together to celebrate something or special occasion, and } \\
\text { the position when always eating in the sit position. }\end{array}$ \\
\hline & & $\begin{array}{l}\text { Reclining/Leaning } \\
\text { Back }\end{array}$ & $\begin{array}{l}\text { No specific word for this activity. However when someone is fishing or on the } \\
\text { throne, there is the possibility to lean back. }\end{array}$ \\
\hline & & $\begin{array}{c}\text { Drink } \\
\text { Eat }\end{array}$ & $\begin{array}{l}\text { Drink sweet coconut water from coconut trees. } \\
\text { Eat Coconut is mentioned. In 'kenduri,' the main activity is also eating. There } \\
\text { are also many kinds of fruits that existed to be eaten in the garden. }\end{array}$ \\
\hline
\end{tabular}




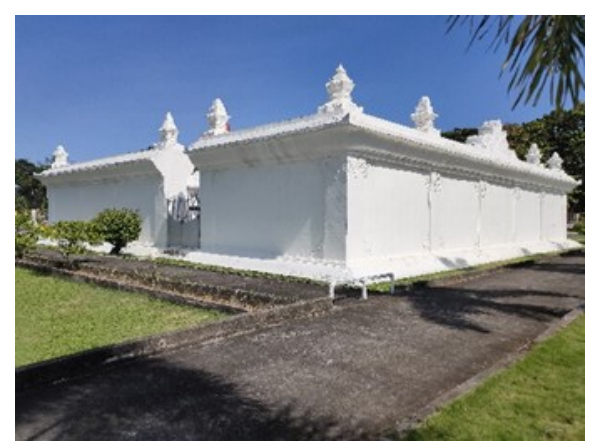

Figure 4. Kandang- considered a cemetery, one of the buildings remains on the Taman Ghairah site (source: Author)
All the physic characters were mentioned in the manuscript explicitly and implicitly. The non-physic characters were not mentioned in the same word. However, it is described precisely to the same character as in Islamic sources. The characters of the user were described either explicitly or implicitly, the same as the garden described in the Quran and Hadits.

\section{THE CONCEPT OF THE GARDEN}

The last component that was compared in this study is the concept of the garden. It consisted of nine elements of the concept: order, space, form, texture, pattern, light, movement, garden element, and user [11]. The comparison of the garden concept between the Islamic concept and the Bustanussalatin is shown in table 3.

Table 3. The Concept of the Garden

\begin{tabular}{|c|c|}
\hline Order & $\begin{array}{l}\text { There are no specific criteria. However, it is worth notic- } \\
\text { ing the concept of tawazun (balance) according to God's }\end{array}$ \\
\hline Space & $\begin{array}{l}\text { It is hinted that the garden of Heaven is spacious and } \\
\text { can be used by a wide range of users at the same time. }\end{array}$ \\
\hline Form & $\begin{array}{l}\text { There are no definite rules about the shape, but the } \\
\text { shape used must not resemble God's creation (humans } \\
\text { and animals) }\end{array}$ \\
\hline
\end{tabular}

Texture There are no specific rules about the texture. It is indicated that any texture is allowed as long as it is practical and does not violate sharia (Islamic law).

Pattern There are no specific rules about the pattern, but there are rules regarding images

Light There is no specific concept of light, but it is described as the garden in Heaven that was shady, and there is no overheating light. There is also the use of shade to protect from light/heat.

Mobility There is no specific concept of mobility, but it is indicated that accessibility is significant.

Garden There are various elements of the garden mentioned Element soft elements (water, vegetation, fruits, and animals) and complex elements (buildings, doors, and other elements such as pillows, tapestry, couch, glasses, cup, plate, vessel)

User The garden can be public or private. It is also opened to all users as long as it does not violate sharia.
Bustanussalatin description

The river laid right in the middle of the garden indicating the balance order of the garden

It is mentioned that the garden was spacious.

Many building forms existed in the garden. There are at least two kinds of elements that resemble God's creation. First, the dragon statue at the entrance of the river. The last one was Balai Rekaan Cina, which was carved by elephant, poultry, dragon, and tiger.

Some textures mentioned were stone, rough white sand, teak wood, black rock, golden color copper, dragon scales looked like tin, many kinds of gems, white stone, sago palm scales, any kind of woods, carved stone, gold top of the roof, white chalk bruised stone and colorful sand.

There was no specific pattern mentioned except that the garden was divided into a section of the same size by the river.

It is indicated that the garden was shady by numerous trees in the garden. There was also a description of the enormous tree which looked like a giant umbrella in the middle of the garden which indicated the shady situation.

The garden's location was near the palace on the north side and can be accessed by the door directly from the palace.

There were various elements of the garden mentioned: soft elements (water, river, pools, vegetations, flowers, trees, and animals) and hard elements (buildings, doors, masjid /mosque, tower, and balai).

The garden belonged to the palace, which was indicated that it was a restricted area and opened for the member of the palace only. However, it is opened to the public on special occasion when the King invite the people in the 'kenduri' (special occasion in Aceh culture)
All of the concepts mentioned in the Islamic source were implemented in the Aceh garden, as mentioned in Bustanussalatin.

From the comparison above, most of the elements, characters, and concepts of the garden in Aceh
Garden mentioned in Bustanussalatin were precisely the same as the Islamic garden according to the Islamic source such as the Quran and Hadits. In comparison, some other elements, criteria, and concepts are similar in some ways. 


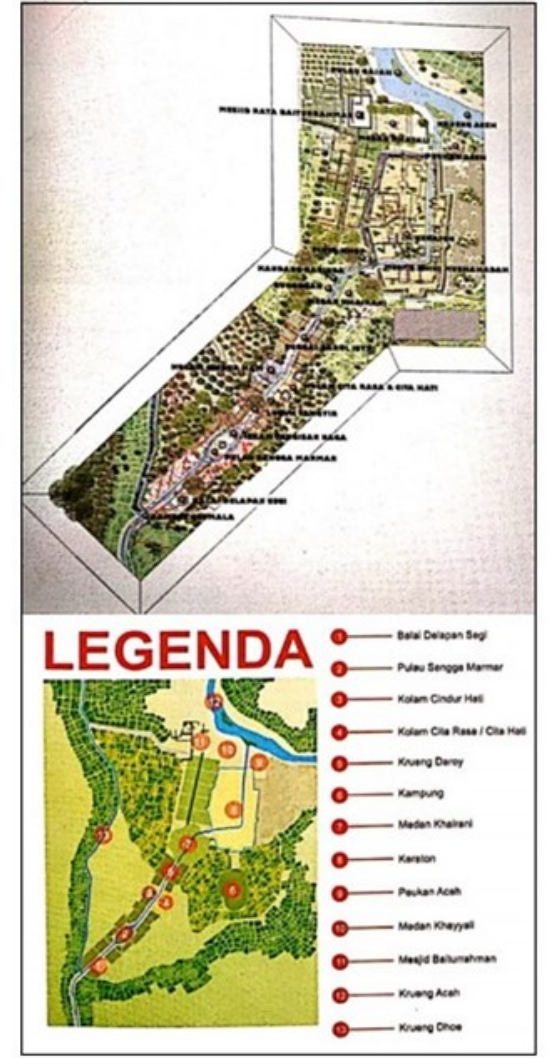

Figure 5. Reconstruction of Bustanussalatin by Arief in 2008 showing the model/prototype (above) and the map of the historical garden (below)(Source: Arief, 2008)[10]

\section{RESTRICTION/BOUNDARY IN SHARIA (ISLAMIC LAW) \\ Besides exploring the three components from} the keywords that existed in the Quran and Hadits in picturing Heaven, Jannah et al. also provide the restriction in Islamic law [11].

The comparison between this restriction in Islamic law and the implementation in Aceh garden, according to Bustanussalatin is shown in table 4.

From the comparison above, it is seen that the garden in Bustanussalatin disobeys the restriction of the elements of the Islamic Garden. There is also an infraction in characters of the garden about luxury, even though it cannot be judged whether or not the intention of the King was for showing off. Meanwhile, it can be stated that there is no infringement in the activities.

Table 4. Sharia Restriction About Elements, Characters, and Activities in Islamic Garden

\begin{tabular}{|c|c|c|}
\hline Criteria & Subcriteria & Bustanussalatin description \\
\hline $\begin{array}{l}\text { Restricted Ele- } \\
\text { ments }\end{array}$ & $\begin{array}{l}\text { Using the form of humans } \\
\text { and animals, for example, } \\
\text { in the statue } \\
\text { Using gold and silver mate- } \\
\text { rials }\end{array}$ & $\begin{array}{l}\text { There was a statue in dragon form. There are also some animals carved in one of the } \\
\text { buildings in the garden. Except for those two features, there was no other infor- } \\
\text { mation indicating human or animal form. } \\
\text { There were some accessories in the garden using gold and silver materials. }\end{array}$ \\
\hline $\begin{array}{l}\text { Restricted Char- } \\
\text { acters }\end{array}$ & $\begin{array}{l}\text { Mixing the goodness and } \\
\text { the badness } \\
\text { Showing off the luxury and } \\
\text { exaggerated }\end{array}$ & $\begin{array}{l}\text { There is no information about these characters mentioned. } \\
\text { The existence of the enormous garden itself was a luxury. However, there is no infor- } \\
\text { mation on whether or not the King is showing it off. Instead, he often invites guesses, } \\
\text { including his people, to enjoy the garden in the 'kenduri' activity. }\end{array}$ \\
\hline $\begin{array}{l}\text { Restricted Activ- } \\
\text { ities }\end{array}$ & $\begin{array}{l}\text { Associating the God (Allah } \\
\text { SWT) } \\
\text { Denying sunnatullah } \\
\text { Vandalism } \\
\text { Approaching zina (free sex) } \\
\text { Unavailing/Useless }\end{array}$ & $\begin{array}{l}\text { There is no information mentioned about this activity-instead, people who enter the } \\
\text { 'Kandang' spelling the praise for the Prophet. } \\
\text { There is no information mentioned about this activity } \\
\text { There is no information mentioned about his activity } \\
\text { There is no information mentioned about this activity. The main activities in the gar- } \\
\text { den were for hobbies and leisure. It cannot be judged that could be categorized as } \\
\text { unavailing activities because there is no information about the quantity of time used } \\
\text { in the garden }\end{array}$ \\
\hline
\end{tabular}




\section{CONCLUSION}

From the result and discussion above, it can be concluded that the Aceh Garden in the $17^{\text {th }}$ century, as mentioned in the Bustanussalatin manuscript, represented the Islamic Garden as mentioned in the Islamic source such as the Quran and Hadits picturing the garden in Heaven. However, there was some restriction from the sharia that was disobeyed in the garden. Although we could consider some factors that may influence the garden in that era, it is not the aim of this study. Therefore, further research is needed to determine it.

\section{REFERENCES}

[1] D. Lombard, Kerajaan Aceh Zaman Sultan Iskandar Muda (1607-1636). Jakarta: KPG, 2014.

[2] N. AS, "Gunongan Kesultanan Aceh (Kajian Arkeologi Sejarah)," Jurnal Adabiya, vol. 16, no. 31, pp. 29-46, Agustus 2014.

[3] J. Harun, "Bustan Al-Salatin , 'the garden of kings': a universal history and $A D A B$ work from seventeenth-century ACEH," Indonesia and the Malay World, vol. 32, no. 92, pp. 21-52, Mar. 2004, doi: 10.1080/1363981042000263444.

[4] S. B. A. L. Khan, Sovereign Women in a Muslim Kingdom The Sultanahs of Aceh, 1641-1699. Singapore: NUS Press, 2017.

[5] N. Man, Jamil, and Yusof, "The elements of Landscape in Islamic Courtyard Design: Case Study of Bayt Al-Suhaymi Museum in Cairo,
Egypt and Alhambra Granada, Spain," International Journal of Academic Research in Business and Social Sciences, vol. 7, no. 3, pp. 653-667, 2017.

[6] N. Ansari, "The Islamic Garden." CEPT University, 2011.

[7] H. H. Md Jani, N. Z. Harun, M. Mansor, and I. Zen, "Islamic Garden Concept in Response to Landscape Design," ajE-Bs, vol. 3, no. 11, pp. 3845, Nov. 2018, doi: 10.21834/aje-bs.v3i11.332.

[8] A. Reid, Asia Tenggara Dalam Kurun Niaga 14501680 Jilid 2: Jaringan Perdagangan Global. Jakarta: Yayasan Pustaka Obor Indonesia, 2020.

[9] A. Lac, "Content Analysis," in Encyclopedia of Adolesence, 2nd ed., Switzerland: Springer International, pp. $1-5$.

[10] K. A. Arief, Ragam Citra Kota Banda Aceh: Interpretasi Sejarah, Memori Kolektif, dan Arketipe Arsitekturnya. BRR NAD-Nias: Pustaka Bustanussalatin, 2008.

[11] M. Jannah, W. Q. Mugnisjah, and A. Gunawan, "Kajian Konsep Taman Islam Berdasarkan Al Quran dan Hadits," El-Harakah, vol. 17, no. 1, p. 1, Sep. 2015, doi: 10.18860/el.v17i1.3082.

[12] Z. Poursafar, "The function of Plants in Asian Gardens: A Review on Asian Landscape Architecture," International Journal of Applied Environmental Sciences, vol. 11, no. 2, pp. 525-533, 2016.

[13] The Holy Quran. 